\title{
The Influence of Greco-Roman Literature on the Poetry of Ahmad Shawqi
}

\author{
Nada Yousuf AL-RIFAI \\ College of Basic Education, \\ PAAET, Kuwait
}

The paper consists of an introduction and three main parts. Part I is a reading of Shawqi's poem "Aristotle." Part II deals with Shawqi's epic poetry. Part III looks at Shawqi's poetic theater.

Ahmad Shawqi (1868-1932) was one of the finest Arabic-language poets and dramatists to pioneer the modern Egyptian literary movement; Shawqi was most notable for introducing poetic epics and drama to the Arabic literary tradition. Shawqi, deemed the "Prince of Poets" and one of the greatest Arabic poet laureates, was raised in a privileged setting with Turkish, Kurdish, Circassian, Greek, and Arab roots. As Shawqi was very relevant to the Khedive Palace, the Khedive sent him, in the late nineteenth century, to France to continue his studies in law and learn about French literature at the Universities of Montpellier and Paris. While in France, he was heavily influenced by the works of French playwrights, most notably Molière and Racine. The evident phenomenon in Shawqi's epic and theatrical poetry is influenced by the French classical school, which derived its subjects from the tragedies of Greek and Roman history. In this pattern, Shawqi derived the topics of his tragedies from Egyptian and Arab history.

Introduction to this research:

A brief biography of Ahmad Shawqi (1868-1932):

Shawqi's poetry collection (Al-Shawqiyat) contained 11320 lines, and his lengthy poem (The Arab countries and the great persons of Islam) 


\section{The Influence of Greco-Roman Literature on the Poetry of Ahmad Shawqi}

1365 lines, while his theatrical poetry reached 6179 lines. In addition to his unknown poetry "Al-Shawqiyat Al-Majhoula," published by Dr. Sabri AlSarbouny, which reached nearly 4,700 lines, witnessing Shawqi's literal fertility and rich creativity made him worthy of being the poet of Arabism and Islam in modern times.

Shawqi studied in Egypt then completed his studies in Europe, where he was significantly influenced by the European medium, the European lifestyle, and European poetry. The influence of both environments remained apparent in his life and in his poetry. In his introduction of Shawqi's first poetry collection, Dr. Muhammad Hussein Heikal said:

When your review the parts of Shawqi's poetry collection, you almost feel that you are in front of two different men with no connection between them; one is a believer whose heart is filled with faith, while the other is a worldly life man who sees in the life's pleasures the best hopes and objectives, yet both of them is a naturally disposed poet reaching the top heavens of poetry, both of them being an Egyptian who loves Egypt to the extent of sanctification and worship. (Shawqi, n.d.)

Shawqi reached unlimited ranges of talent, fame, genius, and immortality, a thing that authorized him to cross his country's borders to other Arab countries. He proved through his literary life that, similar to the story, the novel, and the theater, poetry can be unique, can invade any field that deals with various purposes, and can compete with prose in dialogue accuracy and the eloquence of performance and acting. Shawqi, in his poetry plays, kept pace with great novelists, such as Shakespeare, Racine, Victor Hugo, and others, and filled that gap which no Arabic poet had filled before him.

Shawqi was able to combine between the ancient and the modern by adding the Islamic character to the old religions and highlighting the reality of monotheism advocated by religions since ancient times. This trend also prevailed in his poetic plays as well. (Abdul-Wabah, 1987, p.7) Part I : A reading of Shawqi's poem "Aristotle." 


\section{Nada Yousuf AL-RIFAI}

In 1924, Dr. Ahmad Lutfi Pasha Alsayed issued an Arabic translation of Aristotle's "Nicomachean ethics." Ahmad Lutfi AlSayed (January 15, 1872 -March 5, 1963) was an Egyptian intellectual, anti-colonial activist, and the first rector of Cairo University. He was an influential person in the Egyptian nationalist movement and used his position in the media to strive and gain an independent Egypt from British rule. He was also one of the architects of modern Egyptian nationalism, as well as the architect of Egyptian secularism and liberalism. He was fondly known as the "Professor of the Generation."

In his book, "The Story of my Life," Al-Sayed (2012) explained why he had translated Aristotle's "Nicomachean ethics":

Why I translated Aristotle:

Since the Arab philosophy was based on the philosophy of Aristotle, no wonder that his views and his doctrine are the most harmonious with our current works, and the nearest way to transfer knowledge to our countries and become acclimated with them hoping that it would create in the East Renaissance, what was produced in the Western Renaissance.

Aristotle was not like any other teacher, specialized in a special type of knowledge, yet he was a teacher of philosophy, politics, and sociology. The Arabs rightly called him, the first teacher, and Dante described him as "the teacher of those who know." Therefore I translated in 1924 his book the book of "Morality" which is an introduction to the book of Policy, since a large part of it paves the way for the subject of the book of policy. Thus I translated it for the benefit of Arab readers. (p. 101)

Ahmad Lutfi Pasha Alsayed

When Dr. Ahmad Lutfi translated Aristotle's "Nicomachean ethics" into Arabic, Shawqi was very pleased with it, and sent to him the following admiring congratulatory poem:

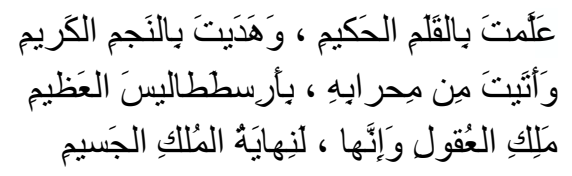




\section{The Influence of Greco-Roman Literature on the Poetry of Ahmad Shawqi}

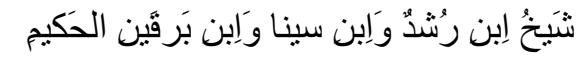

$$
\begin{aligned}
& \text { مَن كانَ في هَدي المَسيح وكَكانَ في رُشَّدِ الكَليم }
\end{aligned}
$$

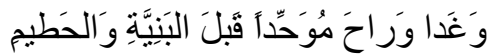

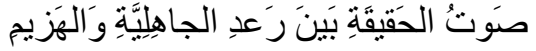

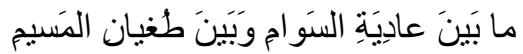

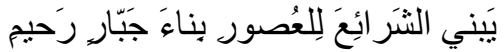

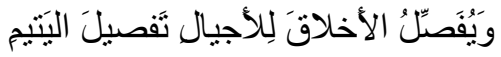

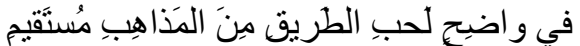

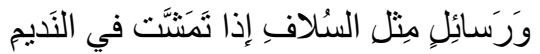

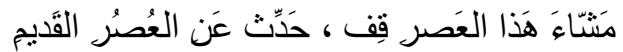

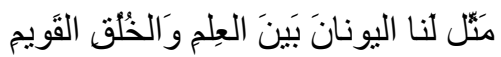

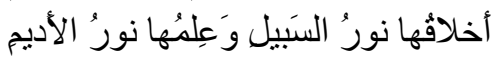

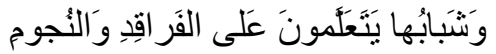

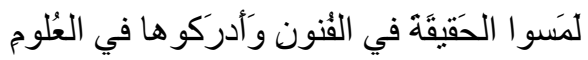

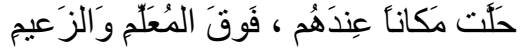

You taught by the wise pen, guided by the noble star and brought great Aristotle from his niche.

The King of the mind, which indeed is the utmost of massive kingdoms

The master of Ibn Rushd (Averroes), and Ibn Sīnā (Avicenna)

and the wise son of Barqeen village*

Who had Christ's guidance and Moses' reason.

He came and went as a monotheist, before the structure of the holy Ka'aba, the voice of truth in between the ignorance thunderclaps.

Between the ordinary congregation and the tyranny oppression,

It builds the laws for ages, a powerful kind build.

It elaborates the ethics for the generations as did our prophet, who was an orphan.

In an apparent wide road of straight doctrines

Messages like old wine when it spreads into its companion

$\mathrm{O}$ apostle of this age! Talk to us about old times, 


\section{Nada Yousuf AL-RIFAI}

Represent to us Greece with its knowledge and straight ethics, Its morals are the road's light, its knowledge is the earth's light And its youth who learnt from the high stars.

They sensed the truth in Arts, and reached it in knowledge It befell by them a place, above the teacher and the leader.*

* In reference to Ahmad Lutfi

* In reference to Aristotle's famous saying: (Plato I love, but I love Truth more). Amicus Plato, sed magis amica Veritas.

Part II : Shawqi's epic poetry.

Epic poetry in Arabic literature:

Think with me a little bit about the history of Greece, to which returns the modern and ancient human civilization, and think a little bit about the history of the Arabs, which is also due to the Islamic civilization in some respects. On what did the Greek life in Greece nomadism and its first civilization? On what was the Arab life in the Arab nomadism based? On poetry. We can say: on poetry alone; Arabs and Greece are similar in this aspect; when you look for their philosophers and wise men, their leaders and politicians, and their social masterminds at times of desert life, you will not find but poets. Then when you look for their philosophy and religion, their various systems and their mental and emotional life, you would but find it in poetry. Poetry, therefore, is the first manifestation of the strong social life of these two nations.

In modern times, when modern poets, wished to compose theatrical stories and lyrics, they resorted to models of the Greek poets, thus composing stories and poems as did the Greece, influenced by the "Iliad" and the "Odyssey". (Hussein, 1925, p.7)

The similarities between these lengthy poems and the epics are that they are very long and that the heroes are characterized by extraordinary 


\section{The Influence of Greco-Roman Literature on the Poetry of Ahmad Shawqi}

courage and mixed with historical events, myths, and legends, as noted by Roger Allen in his book, "An introduction to Arabic literature" (2003) where he described them as popular epics.

Although the Arabs before Islam were pagans and had their legends and myths, their nature, their environment, and their journey in space and time made them belong to the Lyric poem rather than the theater and the epic. This poetic art did not exist in our old eloquent literature, yet we had the so-called "Seyar Sha'biya" (lengthy folk biographies) as the "sirah" biography of "Antara" and the biographies of "Saif bin Dhi Yazan," "Abu Zaid Al-Helaly," and "Ali Al-Zeibaq," which were very close to the art of the epic.

In the modern time, some epic works appeared, although they do not match the old epics but had some of the epic features, such as the epic "Al-Ghadeer" by Paul Samir, who was impressed by the championship of Prophet Muhammad's cousin, peace be upon him, composing an epic that depicted his heroic and miraculous achievements.

Shawqi was closely associated with the state of the Ottoman Empire; Egypt was subordinate to it, therefore he praised its sultan, Abdul Hamid II, calling on Muslims to furl around it because it was the bond that bound them together and supported them. When the Ottoman Empire won its war with Greece in the year 1887, Shawqi wrote a great lengthy poem titled "Echo of War," in which he praised the victories of the Ottoman Sultan. It was lengthy like an epic poem, divided into parts like the songs in an epic. Three parts, "The paternity of the prince of believers," "The happiest accession to the throne," and "A great dream and a greater oppression," which mourned the fall of Abd Al-Hamid II in a coup by the committee of Union and Progress, comprise one of Shawqi's fantastic Ottoman masterpieces, entitled "The Ottoman coup and the fall of Sultan Abd Al-Hamid." 


\section{Nada Yousuf AL-RIFAI}

At the beginning of the modern Arabic Renaissance, Muheb AlDeen Al-Khatib believed that Arabs and Muslims should have their own

epics based on their real history, containing struggles between right and wrong, surpassing the Greek and Roman legends and fantasies. Thus he went to Ahmad Shawqi, the most famous poet of the modern era at that time, and offered him the idea of an Islamic epic; however, Shawqi kept silent, not announcing acceptance or rejection, so the man departed to Ahmad Muharram and offered him the idea, which he immediately accepted. Ahmad Muharram began composing and publishing the epic, called the "Islamic Iliad" or "the glory of Islam," in parts in the journal of "Al-Fath." Muharram was the first pioneer in this road, paving it for other modernist Arab poets. The paradox was that Shawqi surprised people after the emergence of "Muharram's Iliad" by publishing his prolonged poem, known as "Arab countries and the greats of Islam," observing the movement of Islam since the dawn of its call until his day.

The Arab countries and the greats of Islam:

"Arab states and the greats of Islam" is a prominent icon in the history of Arabic literature and its poetry. It is a lengthy poem that consists of 1729 lines and views the history of Islam since its rise until the fall of the Fatimid state in Egypt, including 153 lines about the biography of Prophet Muhammad, peace and blessings be upon him, and his orthodox caliphs. Shawqi completed it, retracing his tour through the history of Islam by mentioning the great men's biographies and the countries in the Arab Umayyad, Abbasid, and Fatimid states. It is worth mentioning that Shawqi wrote this lengthy poem while he was suffering the pain of exile after the British had exiled him from Egypt, due to a poem in which Shawqi satirized Evelyn Baring, 1st Earl of Cromer, the British controller-general in Egypt. Shawqi chose to be exiled to the Andalusian territory, Barcelona in particular.

Exile to Spain: 


\section{The Influence of Greco-Roman Literature on the Poetry of Ahmad Shawqi}

While Shawqi was in Spain, he learnt their language; spent his time reading history books, especially the history of Andalusia; worked on carefully reading the main sources of Arab literature; and visited the ancient monuments of the Muslims and their culture in Seville, Cordoba, and Granada. These readings resulted in Shawqi composing his lengthy poem, "Arab states and the greats of Islam," which includes 1400 lines distributed in 24 poems; it tells the history of the Muslims since the era of prophecy and the caliphate, and despite its magnitude it is closer to educational poetry. It was published after his death.

His lengthy poem "The Arab countries and the greats of Islam" started with an introduction, and then he talked about: the language of the Arabs, their history, the Motherland, The Sacred House of Makkah, the Biography of the Prophet Muhammad, the orthodox Caliphs, the Umayyad state, The Abbasid Caliphate, the State of the Fatimids.

I, the researcher, think that exiling Shawqi was the greatest gift that the British granted to Arabic literature, because in his exile, Shawqi wrote his masterpieces of longing to his homeland.

Part III : Shawqi's poetic theater.

The theater is one of the oldest literary arts known to human civilization, since the Greeks established their theaters on religious and national occasions long ago. The Greeks, through theater, recognized tragedy and comedy, tackled religious and social topics, and educated their community. The Romans were the first to take from Greek theater, then the French, the British, the Germans, and then the Arabs.

Drama is a new genre to the Arab culture, no older than a century and a half; it began with the attempts of Maroun Al-Naqash in the middle of the nineteenth century, but the play faltered later and then succeeded in the second half of the twentieth century. Poetry theater had to benefit from global dramatic culture; therefore Moliere, Shakespeare, and Brecht clearly influenced the prose plays, in general and in poetry plays in particular, 


\section{Nada Yousuf AL-RIFAI}

which contained the most important features of contemporary technologies in poetic drama.

The establishment of the Khedivial Opera House in Cairo, on November 1, 1869, encouraged some Lebanese who were interested in theater to quote ideas from European literature and characterize them with their local colors.

The theater was not known in its contemporary sense before the middle of the nineteenth century in the Arab world. After Al-Naqqash's death (1855), his followers spread, establishing theatre troupes and composing plays; one of his followers was Saleem Al-Naqqash (d. 1884), who wrote and translated a number of plays, including "The Punter," "The liar," and "The unjust," which angered the Khedive Ismail because he thought it was a critique of his methods of ruling, and thus drove the troupe out of Egypt. Another of Al-Naqqash's followers was Adeeb Ishaq (18561885), who wrote and translated some plays, such as "Charlemagne" of Victor Hugo; Ibrahim Al-Ahdab (1824-1891), who wrote many plays, including "Alexander the Great - translated," and Khalil Al-Yazji (18561889) who wrote "Virility and fulfillment," were also followers of AlNaqqash.

Saleem Al-Bustani (1848-1884) wrote "Alexander," " Qays and Lubna," and "Zenobia." Najib Al-Haddad (1867-1899) translated more than ten plays, including "King Oedipus" by Sophocles, "The Miser" by Molière, and "Love Martyrs" (Romeo and Juliet) by Shakespeare and composed a number of plays, including "Al-Mahdi and the opening of Sudan." Farah Anton (1874- 1922) translated a number of plays for the theater, including "The Sphinx is moving," "Street girls and seclusion girls," "Sultan Saladin and the Kingdom of Jerusalem," and "Modern and ancient Egypt" in 1913, which was the beginning of the history of eastern acting, performed by George Abyad and his band on July $5^{\text {th }}, 1914$. 


\section{The Influence of Greco-Roman Literature on the Poetry of Ahmad Shawqi}

Along with the modern Arab renaissance and the opening of the Arab-Western cultural connection, the theater became a common literary template that enjoyed growing interest. A comedy theater was established in the reign of Khedive Ismail in 1869, as well as the old Khedivian Opera House, in which the Middle Eastern opera "Aida" by Faraday of Italy was first performed.

However, the first to insert the theatrical art into the Arab countries was Maroun Naqqash, of Lebanese origin, who acquired it from Italy when he traveled there in the year 1846. The first play he presented to the Arab audience in Lebanon was "The Scrooge" by the French playwright Molière in late 1847. Theatrical art was at first, however, not welcomed or encouraged.

In Egypt, the first Arab theater was established by Yaqub Sanou, nicknamed "Abu Nadara," in the year 1876. Within two years, around thirty-two plays were performed in his theater, some of which were adapted from Western literature that he adapted with his own local style, and others whose subjects dealt with social problems. Sheikh Abdullah Al-Bustani (1854-1930) was also a prominent figure, especially with his play "Herod's killing his two sons."

The Egyptians became acquainted with the theater during the French campaign at the end of the eighth century, and later on when they became more connected to Europe during the era of Muhammad Ali and his sons; some Egyptianized Levantines transported this art to Egypt, which was, in its infancy, just a weak imitation of what they saw in Europe.

The Levant Maroun Al-Naqqash is considered the founder of Arab theater, perhaps preceded by Yaqub Sanu, nicknamed as "Abu Nathara." Maroun had visited Italy and checked out the art of acting there; he greatly admired it and thought of transferring it to his country. 


\section{Nada Yousuf AL-RIFAI}

Among the pioneers of this art in Egypt was Maroun Al-Naqqash, who established a theater in Alexandria in 1876 and was followed by the other Levant teams.

The first attempt to write a poetic drama in Arabic literature was by Khalil Al-Yazji in his play "Al-Muru'a wa Al-Wafaa'," published in its first edition in 1876. It was followed by other poetic plays that were mixed with rhymed prose by a variety of writers and actors.

The Arab theater began to receive private groups of its students from the European missions, who took interest in translating works from the Western theater into Arabic. Among the most important of those who were greatly affected by the Western theater was Ahmed Shawqi during his mission to France and his exile to Spain. After Shawqi came the poet Aziz Abatha, who considered Shawqi as his leader, then came the poet Ali Ahmad Bakathir and the poet Salah Abdul Sabour, who wrote the tragedy of Al-Hallaj, and "Layla and her mad lover." Many other play writers appeared; but the most famous one to be influenced by the poetic theater, particularly by Shakespeare and the Racine Theater, was Ahmad Shawqi.

Theatrical poetry

Acting remained unknown in Arabic poetry until Shawqi came and inserted acting into it. Firstly, at the beginning of his literary life, he did it only as an attempt during his scholarship in France, but it did not take its final shape until the end of his life in "Ali Beck the Grand."

Shawqi returned to Egypt to be employed in the palace and be occupied away from this new Western art, which he dreamt to insert into our literature and language in the beginning of his life, and remained uninterested in it until he was exiled to Spain during World War 1.p79 


\section{The Influence of Greco-Roman Literature on the Poetry of Ahmad Shawqi}

After the war, Shawqi did not return to the palace or his official life, yet he devoted himself to his poetry and his art. He wrote poetry for the national emotions of his people and the nationalist emotions of the Arab peoples. Later on, he returned to the art of acting, breaking through it, composing seven plays, six of which were dramas and one was a comedy, taking into account in the tragedies that they should satisfy the Egyptian audience in particular and the Arab audience in general. Three of the tragedies depicted the national emotions, namely: "The Death of Cleopatra,"" Cambyses," and "Ali beck the Grand." The other three depicted the Islamic Arabic emotions, namely: "Layla's mad lover," "Antara," and "The princess of Andalusia." The comedy was "Lady Huda," which he derived from our popular life in the last century and from a special theme in this life, which is the greed of men, ingeniously coupling the elements of laughter and the moral and social significance.

Shawqi's breakthrough into this Western art and composing in it was a new opening and a dangerous action, not only in terms of inserting this art for the first time into Arabic literature, but also because he was resisting the slang stream that overwhelmed the Egyptian theatre and mesmerized the youth, known as Kishkish and Kassar theater. Shawqi strove against this colloquial current and was able to distract young people away from it; he was even able to make them become infatuated by him and his plays when they were performed in an unrivaled manner.

His plays clearly indicate that he read this Western art thoroughly, and it is said that he used to visit the famous Paris theaters during his scholarship. He remained concerning himself with this art until its idea and characteristics were imprinted within him. Hence he started composing his plays, whose theme were about kings and princes supporting duty upon emotion in a conflict, which shows that he had read a lot about the French classical school of Racine, Corneille, Molière and their ilk. (Daif, 2010, p. 80) 


\section{Nada Yousuf AL-RIFAI}

It is also noted that his plays are permeated by parts to be musically composed and sung, as if responding to the trend of the Egyptians and their tendency to sing. The Egyptian colloquial theater before Shawqi was interested in this aspect, thus Shawqi entered it in his plays. Had he studied the western theater carefully, he would have known that the Greece had really entered singing in their plays, but they used to make special meters for singing and others for dialogue. Then they were followed by the Westerners who separated between lyrical acting and theater acting, the former was specialized for the "opera" where acting is a means, not an goal, The goal is music, movements and landscapes. Thus, they had lyrical acting and pure acting. (p. 81)

Despite this, Shawqi's plays are considered a great job, as he was able to egyptianize this European art, and make it an Egyptian Arab art for the first time in our modern history. He retained its old difficult frame, set by the Greeks and Romans, that is, the poetry frame which Europe had left behind since late of the nineteenth century, The writers got fed up with poetry while they tried to portray the human and social problems and its deep psychological analysis, therefore they left it to prose that suits this depth and analysis. Shawqi was not influenced by this prose trend except in one play, namely "Amirat al-Andalus"(The princess of Andalusia). However, Shawqi exerted great efforts in transforming this art into our language and our literature, deserving praise and appreciation. (p. 82)

The plays of the Prince of Poets, Ahmad Shawqi" (1868-1932), represented a new breakthrough and technical leadership in their form and content. Among them was "Ali Beck Al-Kabir" (1893), which he wrote as a student in France. Despite the care given to complete it, he did not bring it out into the light because he did not feel pleased with it. He rewrote it later in 1932, prior to his departure from this world. Shawqi remained obsessed with the theater until the year 1927, when he was crowned as the Prince of Poets, and he saw that this "emirate" should be an incentive for him to 


\section{The Influence of Greco-Roman Literature on the Poetry of Ahmad Shawqi}

complete his theatrical works, quickly producing a historical tragedy, "Cleopatra," in the year 1927. The third of those historical masterpieces was "Cambyses" (1931). From the folklore heritage he wrote "Layla's mad lover" and "Princess of Andalusia" (1932), in the same year in which he wrote his play "Antara." Two plays reflect the contemporary social reality of the poet, namely "Lady Huda" and "Al-bakhilah" (The miser woman).

Shawqi's plays received acclaim and acceptance among the Arab public, especially because the Arab memory is mostly a poetic memory; it also positively interacted with this theatrical form, which tackled many social issues with a historical taste. Shawqi coined his plays in a poetical template, except for "Princess of Andalusia," which he wrote in prose; their themes were inspired by history, except his comedy (Lady Huda), which portrays a social theme of modern life.

Ahmad Shawqi visited the French theaters while studying in France, especially the theater of the comedian Francaise which is the State Theatre, that was and still presents classical poetry plays, both tragedy and comedy, in particular the plays of Racine, Corneille and Moliere, tending to emulate them. (Hawi \& Mandour, 1970, p. 70)

In his play "the death of Cleopatra" Shawqi depicted Cleopatra in the image of the Egyptian queen who was loyal to her homeland. Nevertheless he presented her in his play amid scenes of opulence and temptation prepared to lure Antonio.

Composer Mohamed Abdel-Wahab and singing parts of these plays great popular success, such as broken: I Antonio in the death of Cleopatra, and cut Mount Alnubad in "Crazy Layla." (p. 74)

The lyric theater reached its peak with Shawqi's lyrical poetry, and it became the lyrical focus of his whole art; through it, he moved to the actor and had an impact on the audience. It is from this kernel that Shawqi's artistic advantages and disadvantages spring, as these songs are the extension of what was written by the poet. A look at them and their 


\section{Nada Yousuf AL-RIFAI}

structure shows what was taken into account regarding their lyrical, acoustic, and musical values. Thus in the Song of love and life in "The Death of Cleopatra," the song expresses love, in the Song of death it expresses death, and in the odes of graves it expresses death in the play of "Layla's mad lover." There may be songs of praise, such as when Cambyses praises the Pharaoh, or for a wedding, as in "Ali beck the Grand," when Ali marries Amaal and Antara marries Abla.

Ahmad Shawqi told us in his introduction to the first edition of his book in 1898 how he was impressed by the French literature and poetry during his stay in France and that he wished that the Arab modern poetry would tend likewise and go out of the traditional scope to wider areas and new arts. He also told us how he himself began towards a broader simulation and new arts initiating to simulate that literature. (Shawkat, 1947, p. 36)

In 1927 Shawqi wrote (The death of Cleopatra), which was performed at that time on the Royal Opera stage. The appearance of the poetic novel in the Arabic theater was an important event in the history Arabic language and Arabic literature. Shawqi wanted to accomplish the Arab poetry a mission and to immortalize in it what Shakespeare immortalized in English language. The great welcome which "The death of Cleopatra), received pushed the poet to continue the road in spite of his poor health at that late age. Thus he composed his poetic plays, "Majnoun Layla" (Layla's mad lover), (Cambyses), (Antara), (Lady Huda) , "Albakhilah" (the miser), and finally his novel "Ali Beck Al-Kabir" (Ali beck the grand), which he rewrote its chapters. (Al-Fakhouri, 1986, p. 439)

Shawqi, founder of the Arab poetic theater:

Shawqi's theater was an event in the history of Arabic poetry, which lived a long life without knowing this genre (the theater) in spite of the Arab translation of Aristotle's book of poetry and the latter's tribute to the 


\section{The Influence of Greco-Roman Literature on the Poetry of Ahmad Shawqi}

importance of the theater among the three genres of poetry: the musical, the theatrical, and the epic. Shawqi was the one who filled this desolated gap in the history of Arabic poetry, and on his hands was the birth of this theater, which generated six plays within a five-year period. This was a great achievement for a poet who was to pass a health crisis during this period, which soon caused his death in October 14, 1932. Shawqi was the poet of heritage, through which he grabbed a dimensional variety and here gave a side of his genius in adjusting and renovating, which is the best artistic way to reach an audience not familiar with this genre.

Shawqi's poetic theater

In order to get a distinct poetic theater, Shawqi was initially inspired from history and its stages of legends, but he was also inspired from nature, human nature, and the Egyptian National and National Arab heritages. In regard to the lyrical nature of Shawqi's plays, it does not diminish the advantages of his plays, such as "Layla's mad lover" and "The Death of Cleopatra," which contained immortal lyrics. Shawqi's interest in theatrical lyrics may be explained by his keenness to reach the Egyptian audience. Whatever was said concerning the points of the theatrical weakness of Shawqi, his accomplishment remains significant, especially since he had no front models or examples of the Arab poetic theater to follow.

The stages/phases of Shawqi's poetic theatre:

Ahmad Shawqi reached the top of his glory and felt that he had achieved all his aspirations after he was pledged allegiance as the Prince of Poets, so he turned toward the art of poetic theater, which he had begun during his stay in France. The lyrical and moral side overwhelmed his plays, while the dramatic side was rather weak; however, these drawbacks do not deprive Shawqi's plays of their poetic and lyrical value or deny that his poetry is the dramatic pillar of modern Arabic literature. 


\section{Nada Yousuf AL-RIFAI}

Dr. Su'aad Abdul Wahab (1971), in her book "Shawqi in the eyes of his contemporaries," citing Tanahi (1967):

Here I found a chance to talk to our great poet, whereupon I asked him why he turned to theatrical poetry composing for narrative drama. Shawqi answered saying:

"In my youth I knocked the doors of poetry, not knowing of its reality and mission what I know today. At the beginning of my life I did not find of poetry purposes except praise for a rank or lament for a great person. Then I wanted to have a better mission than this for my poetry. Thus I tackled the Patriots, Islamics and nationalities, and contributed as much as I could, to the national renaissance at the days of Mustafa Kamel, then in the 1919 renaissance, and whatever branched out of these two of scientific and social risings. Later on I yearned to immortalize of this art in the Arabic language what Shakespeare immortalized in the English language because I believe that Arabic poetry - contrary to the accuses of biased people - has room for the narrative play, which is rather easier to be memorized than prose, easier to perform, and has a stronger impact on the audience." (p. 228)

"The poet finds that his mission in the narrative drama is of a wider range, a longer life, and greater benefit, because the theatrical stories are a miniature world on the stage." (p. 229)

\section{Ali Bey The Grand:}

The play (Ali Bey The Grand) was Ahmad Shawqi's first theatrical poetic work. Shawqi wrote it in Paris in 1893 after it was made available to him to be in touch with French literature, and watch plays in the French capital. Shawqi portrayed in these plays the Mamluki reign, and its political and social disadvantages. (p.223)

The play contained the technical elements of a successful play, such as: the plot, complexity, solution, suspense, surprises, and lively dialogue to a large extent. Despite of that, it did not receive the success that Shawqi was waiting for, and he did not see an encouragement to continue writing 


\section{The Influence of Greco-Roman Literature on the Poetry of Ahmad Shawqi}

for the theater at that early time. Therefore he prefered lyric poetry and gave attention to praise poetry, and what was similar to it, like social and political poetry, which would bring him quick excellence, and give him a ride to the post of the Prince's poet (poet laureate), then the Prince of Poets. He did not turn back to writing for the theater till 1927, when the artistic awareness progressed, and the Egyptian Theater flourished, and good featuring teams appeared. Thus he returned to write the well-known series of his plays, and rewrite his first play, trying to avoid what was in it of disadvantages. (p. 225)

This vine (Shawqi's house) was in last month the scene which held landmarks of literary parties and concerts, and every ceremony held at that edifice was difficult to describe however eloquent you were. The prince of poetry is a one of his kind in his parties as much as he is unique in his poetry. Yet nothing concerns me of these celebrations, except the one that the greatest Arab poet set up on the honor of the top actor in the West and his eastern counterpart, I meant by the former the French composer Monsieur Sylvan and by the second his Lebanese disciple "George Abyad", along each is his band At the lead of the party was the much interested Heshmat Pasha the administrator of education, hence Arab and Western literature shock hands under his sponsorship. The minister thanked France's genius actor for taking care of his disciple George Abyad until he became the Middle East's genius actor. Monsieur Sylvan by his turn thanked the minister for activating this art hoping that the Arab acting would reach the success reached by the French. Among the invitees was Elias Effendi Fayyad the well-known Arab writer and poet who translated the famous novels acted by George Abyad. (Al-Zohour, 1912, p. 437-438)

Cleopatra

Cleopatra was surprised that the will of her husband Caesar was to divide his property between his people and his relatives, among them Antony, and to bequeath the throne to his adopted son Octavian. He did not bequeath anything for her or her son from him. 


\section{Nada Yousuf AL-RIFAI}

Cleopatra returned to Egypt after Egypt turned into an internal battlefield over ruling. After many years, it was settled between Antony and Caesar's adoptive son, Octavian.

In the year 43 BC, Mark Antony reached the shores of Egypt and sent a messenger to summon Cleopatra, who was twenty-nine at that time. She invited him to her ship, saying "You are my guest tonight, then let tomorrow come." He fell in love with her and settled in Alexandria.

Antony and Cleopatra married and gave birth to several boys and girls. Romania did not recognize this marriage, Antony's ex-wife Octavia divorced him, and he received the wrath of the Romans.

Events accelerated until the year $30 \mathrm{BC}$, when Rome stood in the face of Alexandria, Octavian against Antony and Cleopatra, and the two fleets fought against each other. Antony was defeated, fatally wounded and carried to Cleopatra, where he died between her hands.

Octavian ordered Cleopatra to go with him to Rome to be held accountable, and she walked handcuffed with her children in his victory procession. She asked him a favor, to be allowed to pour wine on the tomb of Anthony; she went back to the shrine heavily guarded, closed the door, and asked for a basket of figs, saying:

$$
\begin{aligned}
& \text { أأدخلُ في ثياب الذل روما * و أعرَضُ كالسبيِّ على الرجال؟ }
\end{aligned}
$$

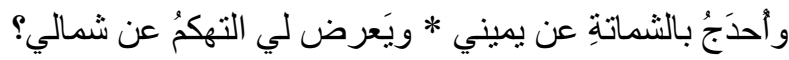

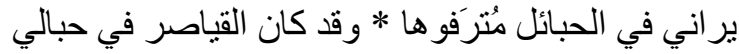

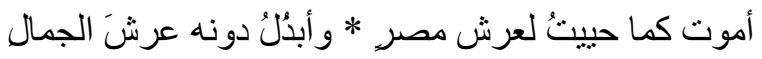

$$
\begin{aligned}
& \text { حياة الذل تدقعٌ بالمنايا * تعالي حية الو ادي تعالي }
\end{aligned}
$$

Should I enter Rome in humiliation?

And be shown to men as a captive?

Be scorned on my right side?

And mocked on my left side?

While their luxurious see me in chains?

After which their Caesars were in my cords? 


\section{The Influence of Greco-Roman Literature on the Poetry of Ahmad Shawqi}

I shall die as I lived for the throne of Egypt, And sacrifice the throne of beauty for it.

The life of humiliation pushes me to death, Come valley snake, come to me. (Shawqi, 1984, p. 540)

Cleopatra took a snake out of the basket of figs and pushed it inside her chest. Within moments the secret poison spread in her blood. When Roman soldiers broke into her room, she was dead.

Cleopatra in literature

Cleopatra has been the topic of circulated playwrights' pens since the time of the European renaissance and until the twentieth century. In French literature, we find a series of plays that deal with some aspects of this legendary character, starting from Étienne Jodelle at the beginning of the Renaissance to Victorien Sardou at the beginning of the twentieth century, and in England from Shakespeare to George Bernard Shaw in the modern era. Even operatic musicians addressed Cleopatra, and perhaps the Opera (Messina), which was composed in 1919, was among the best melodies composed to interpret that story in tunes and melodies.

Both Shawqi and Shakespeare wrote the poetic drama (The Death of Cleopatra) yet when comparing between them we find that the character of Cleopatra as drawn by Shawqi differs in many aspects from that portrayed by Shakespeare. (Zaza, 1997, p. 208)

Cleopatra

Shawqi wanted to show that Cleopatra was driven by her love for Egypt, not her desire for men and playing with their hearts. He wrote his play out of his own vision as an Egyptian poet who belonged to this nation that was ruled by Cleopatra and witnessed these events. This was the most important thing meant by Shawqi in his plays, to highlight the ideals, and foremost the example of sacrifice for the sake of the homeland and for the sake of freedom, honor, and upholding virtuous moralities. 


\section{Nada Yousuf AL-RIFAI}

During the last three years of the life of Shawqi, people were engrossed by his plays, which were performed at that time at the royal Opera Theatre and Azbakiya Park.

It started with the Cleopatra play, and then "Layla's mad lover," and these were followed by his other plays. The emergence of these plays was an important event in the worlds of literature, poetry, and modern theater. Shawqi said (n.d.):

"Before I wrote "Cleopatra" I had seen in the cinema a French queen portrayed in the film as a dissolute woman, and I wondered how many mistakes and lies there are in history, which might be in regard to the author's tendency, his political whim, religious or national inclinations, or his desire to excite the audience!!

As did Shakespeare in English language..!

(Here Cleopatra emerged in my mind, and I said: I think that this queen may have been offended purposely by the historians and they exaggerated in accusing her falsely. This motivated me to compose this theatrical novel about her, because it did not make sense to me that Cleopatra might had been in this dire situation that we see in the books of the historians, and I have found out that the origin of the discredit was brought to her by what was written by "Plutarch", one of the Roman rulers' historians).

And so we find that the most important features of her character in Shawqi's play, summarized in its national significance and in that sacrifice which extended throughout the play, since she revealed her motive behind her withdrawal from the battle of Actium as that she preferred death to life for the sake of her homeland.

The time in which this poetic drama spread is the first half of this century, and especially after the thirties of this century. These plays contain something common to Western romance and something else common to Arabic lyrical poetry, even if they were not purely romantic or lyrical. 


\section{The Influence of Greco-Roman Literature on the Poetry of Ahmad Shawqi}

Shawqi wrote "The Death of Cleopatra" in 1920 as an initiative to contribute to the establishment of an Arab poetic theater, as well as in defense of Cleopatra as an aspect of a national symbol.

Cleopatra, in Shawqi's play, represents the character of the Egyptian queen who loves her country; when she left Antony in the battle of Actium, she said:

$$
\begin{aligned}
& \text { أيها السادة اسمعو ا خبرَ الحرب و أمْرَ القتال فيها و أمْري }
\end{aligned}
$$

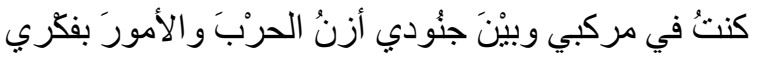

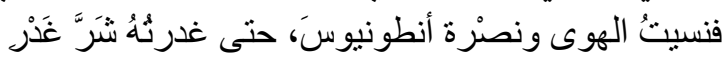

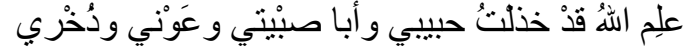

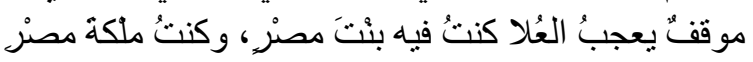

Gentlemen, hear the news of the war, its fight, and my affair, I was in my ship, between my soldiers, thinking it over.

I forgot love, and supporting Antonio, thus I betrayed him utterly.

God knew I had betrayed my beloved,

father of my kids, my support and my supply.

A position which loftiness admires,

In which I was Egypt's daughter, and Queen of Egypt. (Shawqi, 1984, p. $\mathrm{xxx})$

Shawqi felt that his role was to be a registrar of the events of the Middle East and Egypt in particular, and as a historian of the history of Egypt since the Pharaonic era until the contemporary period in which he lived; he found that he had the power to poetize plays, and began reading many references and stories written about Cleopatra, Layla's mad lover, or Cambyses. He even installed a small theater in his house to help him visualize the main characters' positions while composing the plays.

Shawqi used to spew spirit in the historical stories, which he subjected to Arab music and poetry systems. Composer Mohamed Abdel-Wahab chose two scenes from two plays and worked on them, composing their music 


\section{Nada Yousuf AL-RIFAI}

with eternal melodies, that earned him much admiration from his audience. (Abdul-Majeed, 1982, p. 42)

Listen to him singing in "Cleopatra" in the role of Antony:

$$
\begin{aligned}
& \text { انا انطونيو و انطونيو انا } \\
& \text { مالروحينا عن الحب غنى انطى انطوني } \\
& \text { غنتا فى الثوق او غن بنا } \\
& \text { نحن فى الحب حديث بعدنا } \\
& \text { رجعت عن شجونا الريح الحنون } \\
& \text { و بعينينا بكى المزن الهتون } \\
& \text { و بعثنا من نفانات الثجون الثزن الثنون } \\
& \text { فى حواشى الليل برقاو سنى نفى التى }
\end{aligned}
$$

I am Antonio and Antonio is me,

Our souls cannot live without love.

Sing to us, or through us, about longing,

We, in love, are a tale to whom come after us.

The kind wind returned the echo of our agony, And the copious rain cried through our eyes.

We sent from the spits of grieves,

flash and lightning into the night's frames. (Shawqi, 1984, p. 492)

As stated in the diary of the late Egyptian actress Fatma Rushdi (1960):

"One night between the scenes of a play, director (Aziz Eid) knocked on the door of my cabin, then entered along with Prince of the Poets Ahmad Shawqi introducing him to me. It was the first time for me to see him, he sat with me for a while in my cabin and told me that he observes my entire plays one after the other, and admires my acting. At the end of the meeting, he shook my hand saying: I shall grant you a great gift that you deserve."

It was not long till I got the Prince of Poets' gift which was such a great gift, it was so great, it was a miracle, and I performed the role of Cleopatra 


\section{The Influence of Greco-Roman Literature on the Poetry of Ahmad Shawqi}

one of the greatest roles in my life. Shawqi had also brought the musician Muhammad Abdel-Wahab to sing in his play his immortal song "I'm Antonio and Antonio is me."

We used to sit in the Prince of Poets' house (Karmat Ibn Hani) on the Nile. With us was Muhammad Abdel-Wahab singing for Shawqi. Shawqi used to sit beside me and pat kindly on my shoulder going astray absentminded then awakening to write on the papers that were in front of him, his poetic inspirations of the new play. When he did not find a paper he used to write on the sleeve of his white shirt. (p. 54)

Conclusion:

In Shawqi's obituary, As'ad AL-Hakeem said (1930):

Arabic literature remained devoid of optimal theatrical plays for ages till God destined to it in these latest years a fascinator who excels in describing, aligning, and creating new things out of the old. Poetry granted him itself, submitting to him voluntarily. That, gentlemen, is Shawqi and it is sufficient to say that the Arab nation crowned him, while he was alive, as the prince of poetry at the brilliant lavish royal forum, a thing which has never happened to a poet before.

Shawqi submitted his novels to theater, yet he did not receive the graciousness and the popularity to act them as he thought and wished, for several reasons: those related to the environment, and others which were related to the novel itself.

Including the fact that dramatic poetic style was newly acquired and not yet familiar to the ears, thus its image was not carried out to the heart directly but passed the mind before it, and this weakened the impact of the events on the soul. 


\section{Nada Yousuf AL-RIFAI}

In addition to the inexperience of the actors who were unaccustomed to communicate through the language of poetry, besides their weak technical, methodical, and literary experience, placing a chill in the audience's attention. (p. 341)

Shawqi's impressive victory in the poetry circuit and becoming the Prince of Poets irritated some of his rivals, who bitterly criticized his poetic plays, being unable to criticize his poems. If they had been just, they should have said that Shawqi's plays were the best ever written. Shawqi surpassed their cunning by composing further plays, one after another, as if he felt that he had no time to waste in order to reach the supreme model that he was longing to be, and to bridge this notch in Arabic literature, looking towards perfection.

The lyrical and moral characteristics overwhelmed his plays, while the dramatic side was rather weak, and the theatrical movements were slow due to the many long parts of the dialogue, but these drawbacks do not deprive Shawqi's plays of their poetic lyrical value, or deny them from being a poetic dramatic pillar of modern Arabic literature.

Ahmad Shawqi is undisputedly the pioneer of Arabic theatrical poetry, despite the other views of some critics and writers. He portrayed the historical events depicted with an eloquent sensitivity and smooth language. He had virtue, honor of precedence, and leadership in this area.

\section{References}

Ta'ma, J.S. (2006). Shawqi and the West-the Shawqi and Lamartine Session.

Hafiz \& Shawqi (1933). Taha Hussein, Maktabat Al-Khanji, Cairo, Egypt. Abdul-Wahab, S. (1987). Islamiyat Ahmad Shawqi. Cairo, Egypt: Maktabat Madbouli.

Al-Sayed, A.L. (2012).Qisat Hayaty. Cairo, Egypt: Hindawi foundation. Shawqi, A. (n.d.). Al-Shawqiyat. Beirut, Lebanon: Dar Al-Ketab Al-Arabi. 


\section{The Influence of Greco-Roman Literature on the Poetry of Ahmad Shawqi}

Hussein, T. (1925). Qadat al-fikr. Cairo, Egypt: Idarat al-Hilal.

Allen, R. (2003). An introduction to Arabic literature. New York, New York: Cambridge University Press.

Al-Mousa, K. \& Al-Kutab, I. (1997). Al-Arab Al-Masrahiya fe Al-Adab AlArabi Al-Hadeeth. Damascus, Syria.

Shawqi, A. (1970). Duwal Al-Arab wa Uthama Al-Islam. Beirut, Lebanon:

Dar Al-Kitab.

Shawqi, D. (2010). Shawqi Sha'er Al-Asr Al-Hadith. Cairo, Egypt: Al-Hai'a Al-Masriya Al-Amma lil Kitab.

Hawi, E. \& Mandour, M. (1970). A'alam Al-She'r Al-Arabi. Beirut, Lebanon: Commercial Office for printing, publishing and distribution.

Shawkat, M. (1947). Al-Masrahiyah fi shi'r Shawqi. Cairo, Egypt:

Mattba'at Al-Muqtataf wa Al-Muqattam.

Al-Fakhouri, H. (1986). Al-Jame' fe Tarikh Al-Adab Al-Arabi. Beirut, Lebanon: Dar Al-Jeel.

Wahab, S.A. (1967). Shawqi in the eyes of his contemporaries. Cairo, Egypt: Dar Al-Hilal.

Heikal, A. (1971). Tatawwur al-adab al-ḥadith fi Mișr. Dar al-Ma'arif. Staff. (1912, December 1). Al-Zohour Journal. pp. 437-438.

Zaza, D. (1997). Ahmad Shawqi: His immortal lyrical poetry. Private publication.

Abdul-Majeed, A. (1982). Ahmad Shawqi the humane poet. Cairo, Egypt: Dar Al-Ma'aref.

Shawqi, A. (1984). Al-Masrahiyat (The complete plays). Cairo, Egypt: AlHaya'a al-Misriyah Al-Ammah lil-Kitab.

Rushdi, F. (1960). Mudhakkirat Fatimah Rushdi. Cairo, Egypt: Dar alThaqafah.

Ubaid, A. (1930). Dhikra al-Sha'irayn. Damascus, Syria: Al-Maktaba AlArabiya. 